\title{
The Possibility of Applying the Basic Principles of Financial Control in Accordance with the Requirements of ISSAI 200 of the International Standards of the Supreme Audit Institutions (INTOSAI) and its Impact on Internal Control in the Public Sector
}

\author{
Omar Mohammad Al-Hawatmeh ${ }^{1}$ \\ ${ }^{1}$ School of Management and Finance, Department of Accounting, The University of Jordan, Aqaba, Jordan \\ Correspondence: Omar Mohammad Al-Hawatmeh, School of Management and Finance, Department of \\ Accounting, The University of Jordan, Aqaba, Jordan. E-mail: a.alhawtmeh@ju.edu.jo
}

Received: April 17, 2018 Accepted: September 20, 2018 Online Published: October 25, 2018

doi:10.5539/mas.v12n11p415 URL: https://doi.org/10.5539/mas.v12n11p415

\begin{abstract}
The study aimed to clarifying the possibility of applying the basic principles of financial control in accordance with the requirements of ISSAI 200 of the international standards of the Supreme Audit Institutions (INTOSAI) and its impact on the internal control in the public sector in addition to identifying the obstacles that limit the application of the basic principles of financial control according to the requirements of the standard ISSAI 200 of the International Standards of the Supreme Audit Institutions (INTOSAI), and its impact on internal control in the public sector, In order to achieve the objectives of the study and the testing of hypotheses, the researcher designed a questionnaire. This questionnaire was distributed to managers and employees in the internal control of the administrative government units, and (80) were recovered with an adoption rate of $80 \%$ for the statistical analysis purposes. The results showed that the application of the basic principles of financial control in accordance with the requirements of ISSAI 200 of the international standards of the Supreme Audit Institutions (INTOSAI) and its impact on internal control in the public sector in general was high With an arithmetic mean of (4.266) and a standard deviation (0.887) The researcher attributes this result to what has been done in accordance with the laws, regulations, financial and accounting regulations prescribed for the financial control operations. It is in line with the standards assigned to it by the international standards of the Supreme Audit Institutions (INTOSAI). The obstacles that limit the application of the basic principles of financial control in general moderately came with an arithmetic mean of (3.417) and of (1.118). The researcher attributed this result to the existence of some obstacles, the most important of which is non-specialization and noncompliance with the development of the regulations and instructions with the international standards of the Supreme Audit Institutions. Finance and Accounting (INTOSAI) and others as stated in the results of the study. Based on the results of the study, the researcher recommended the need for attention employment staff and work to keep pace with the development and modernization of international standards of Supreme Financial Control and Accounting INTOSAI internal control system in terms of training and development and keep up with scientific and practical progress need to emphasize the re-drafting of some legislation and instructions for some of the financial aspects and the need for harmonization and cooperation Continuous and continuous between the legislators and the applicable bodies of the standards to reach a consensus and appropriate in some of the minor or fundamental differences between the law and the standard and other Recommendations.
\end{abstract}

Keywords: control, internal control, financial control, administrative government units

\section{Introduction}

\subsection{Introduce the Problem}

The main function of the SAIs is to consider whether public funds have been disbursed in an economical and efficient manner in accordance with existing rules and regulations. SAIs must be independent of the entities under their control and be protected against any form of external effect. INTOSAI provides mutual support to SAIs and promotes exchange of views, knowledge and experience among them, and is a spokesman for SAIs within the international community and supports continuous improvement among its members. 
The internal auditor in the public sector is required to assist government administrative units to improve their operations. The internal control profession in the public sector is one of the foundations of the strong governance of the sector. The process of examination and accountability is part of the accountability of the public.

\subsection{Explore Importance of the Problem}

The value of common understanding of independence considered as a basis for the auditor's credibility. The internal control function can be organized and implemented at several levels within the administrative unit. The attention of financial supervision has increased as a result of the ongoing development from one year to another in the public sector through the mechanism of work and the followed procedures.

The transformation and change in some of the audit procedures of the Audit Office, especially from detailed monitoring to test control (sampling method), cancellation of the previous audit and the continuation of the subsequent audit. However, this requires the need to emphasize the existence of an effective internal control system in all fields. Thus, this is done so that financial control and evaluation can be relied upon and trusted (Arab Group of Supreme Accounting and Financial Control in 2010, p. 210).

The study aims to clarifying the possibility of applying the basic principles of financial control in accordance with the requirements of ISSAI 200 of the international standards of the Supreme Audit Institutions (INTOSAI) and its impact on the internal control in the public sector.

\section{Study Problem}

\subsection{State Hypotheses and Their Correspondence to Research Design}

2.1.1 Is it possible to adopt the international standards of the Supreme Audit Institutions of INTOSAI in the public sector?

2.1.2 Is it possible to applying ISSAI 200 "Fundamental Principles of Financial Control" in government administrative units?

2.1.3 Is there an impact on internal control when applying ISSAI 200 "Fundamental Principles of Financial Control" in the public sector?

2.1.4 Are there any constraints that limit the application of ISSAI 200 "Fundamental Principles of Financial Control" in the public sector?

\section{Development of Hypotheses}

In order to answer the questions of the study, the study is based on four hypotheses, which is as follows:

H01: The international standards of the Supreme Audit Institutions (INTOSAI) cannot be adopted in the public sector

H02: The ISSAI 200 Standard "Fundamental Principles of Financial Control" cannot be applied in the public sector.

H03: There is no statistically significant impact on internal control when applying ISSAI 200 "Basic Principles of Financial Control" in the public sector.

H04: There are no impediments to the application of ISSAI 200, "Basic principles of financial control" in the public sector.

\section{The Study Population and those Appointed}

The study population consists of all managers and employees in the public sector (Administrative Government Units).

The researcher distributed questionnaires to all members of the sample (100) personally and recovered 85 of the questionnaires.

Furthermore, it shows the validity of the questionnaires recovered to be valid for statistical analysis purposes (80) at a rate of 0.80 . Thus, this is sufficient to rely on the analysis and results.

\section{Data Sources}

Secondary Data Sources: This source is relied upon by the researcher to obtain secondary data, such as books, periodicals, articles, and electronic information network.

Primary Data Sources: The researcher often depends on the resolution of initial data collection categories used in the study. Hence, this will be developed based on the elements of the problem study and assumptions. 


\section{Literature Review}

Many previous studies were conducted for the possibility of applying financial control in accordance with the requirements of Standard No. 200 of the International Standards for Supreme Audit Institutions (INTOSAI) and its impact on internal control in the public sector. Thus, below are some relevant studies:

\subsection{Al-hawatmeh \& Al-hawatmeh (2106) Study}

Evaluation of Internal Control Units for the Effectiveness of Financial Control in Administrative Government Units: A Field Study in Jordan

The aim of this study is to state the assessment of internal control units for the effectiveness of financial control in administrative government units. Also, it aims at identifying the obstacles that limits the evaluation of internal control units for the effectiveness of financial control in administrative government units. In order to achieve the objectives of the study and the testing of hypotheses, the researcher designed a questionnaire.

This questionnaire was distributed to managers and employees in the internal control of the administrative government units. Out of the 125 questionnaires distributed, 96 were recovered with an adoption rate of $77 \%$. The results showed that the assessment of internal control units for the effectiveness of financial control in administrative government units typically became high with an arithmetic mean (4.099) and standard deviation (0.511). The researcher attributed this result to the data analysis, verification, and validation of the financial transactions. Also, accounting entries which is related to income and expenditure were in accordance with laws, financial regulations, and the prescribed accounting for financial controls. Hence, this is the constraints that limit the effectiveness of the auditors of the Audit Bureau when they conducted financial and managerial control and evaluation in administrative government units. Generally, it became high with an arithmetic mean (3.551) and a standard deviation (0.610). Thus, the researcher attributed this result to the existence of certain obstacles, the most important routine work, lack of incentives and benefits, and others as indicated in the results of the study. Based on the results of the study, the researcher recommended the need for attention to the human element as one of the main components of internal control system. This is in terms of training and development to keep pace with scientific progress and the practical need to emphasize the reformulation of some legislation. Also, it helps with some of the aspects due to the need for harmonization between legislation. In addition, it helps with professional international standards, especially supreme control standards which give importance and effectiveness to financial control and other recommendations.

\subsection{Al- hawatmeh (2106) Study}

The Extent of Internal Control Units in the Government Sector with the Regulatory Standards of the International Organization of Supreme Audit Control Bodies (INTOSAI) in Jordan

The purpose of this study is to statement the extent of internal control units in the government sector with the regulatory standards of the international organization of supreme audit control bodies (INTOSAI). In order to achieve the objectives of the study and the testing of hypotheses, the researcher designed a questionnaire, This questionnaire was distributed to Ministries, Department, dependent and independent institutions, a representative sample was selected to represent Ministries, Departments, dependent and independent institution study sample consist of internal control managers, directors control and employees, Out of the (300) questionnaires distributed, 249 were recovered with an adoption rate of $83 \%$., For the statistical analysis purposes. The results showed that the commitment of internal control units in the Government sector regulatory standards, field standards, reporting standards of the international organization of Supreme Audit controls and accountability in General moderately came with the arithmetic mean and standard deviation, respectively (3.003) (0.535), and (3. 542) (0.610), and (3. 482) (1.022), The researcher attributed this result to it.

Thus, the researcher attributed this result to the mechanism of internal control units action need to action strategies and future plans for its experience, skills and capabilities of both managers and workers employed by administrative government units and the need to strive towards the adoption of regulatory standards for the international organization of supreme audit control bodies (INTOSAI) in the Government sector, Based on the results of the study, the researcher recommended the need for attention to the human element as one of the main components of internal control system. This is in terms of training and development to keep pace with scientific progress and the practical need to emphasize the reformulation of some legislation. Also, it helps with some of the aspects due to the need for harmonization between legislation. In addition, it helps with professional international standards, especially supreme control standards which give importance and effectiveness to financial control and other recommendations. 


\subsection{Hararah (2016) Study}

The Impact of Efficiency and Effectiveness of Financial Control on Rationalize Expenditure Case study (Aqaba Special Economic Zone Authority)

This study aimed to demonstrate The Impact of Efficiency and Effectiveness ofFinancial Control on Rationalize Expenditure (Aqaba Special Economic ZoneAuthority) (ASEZA).The study population consisted of (58) employees working in accounting and internal auditing units in ASEZA. The study sample included all the (58) employees. To achieve the objectives of the study, the case study, Analytical descriptive method is used in addition to multi-simple regression analysis to test the hypotheses of the study. The study found that there is a significant impact of Efficiency and Effectiveness of Financial Control on Rationalize Expenditure (Aqaba Special Economic Zone Authority), It found that there is a shortage in qualifications of employees who work in the financial control unit, shortage in use modern financial techniques and tools, Low level impact on rationalize human resource in ASEZA. The study recommended that training courses are required to enhance qualifications of employees who work in accounting and auditing, employees specialized members in financial control duties, modern accounting and auditing tools and techniques should be used.

\subsection{Shetwer (2014) Study}

The contribution of internal control to improving the financial performance of the economic institution examines the case of the Asian banking institution in Skra (E.G.T.B).

The aim of this study is to highlight the role of internal control to improve the financial performance of institutions by identifying the concept of internal control system, its means and its components, in addition to the procedures applied in its implementation, and thus its contribution to improving financial performance. The study concluded that the implementation of an effective internal control system contributes to the achievement of the objectives of the institution, which is to achieve maximum profit at the lowest costs, which in turn highlights the good level of financial performance and raise the competitive level of the institution.

\subsection{Sawalha et al. (2013) Study}

Modernization of Higher Government Control Methods according to the Requirements of the Privatization: A Case Study in Jordan

This study aims to examine the understanding and recognition of the supreme financial control to keep pace with scientific developments that may occur in the government's internal management. Thus, this was after the restructuring of the financial and economic departments due to privatization and expansion of the private sector and the GATT. This study does not allow the emergence of gaps through financial loss or waste of public money because of broad spending. It keeps the old methods of auditing and control and manual operation of the data before the privatization and restructuring of some economic sectors. It is achieved by developing new programmers and strategies to implement their plans based on international audit standards and performance audit or extensive electronic data in different stages of departmental financial and economic structures. The researcher adopted both the inductive and deductive approach together. This study is a kind of descriptive exploratory survey based on the views or trends in the study sample. However, this study was conducted on a sample of accounting departments' staff in government departments. After applying the study tool, the study sample responses were collected and on verted to raw scores. After then, the duplicates, percentages, arithmetic averages, and standard deviations were obtained. T-test is used to find the differences between the estimates sample members to senior government control methods systems according to the paragraphs of the resolution as the level of statistical significance $(\alpha=0.05)$.

The study found a range of outcomes, including:

6.5.1 Regulators Supreme which represents accounting Bureau Practiced control over the privatization process.

6.5.2 The privatization policies are the result of international pressure to restructure and correct the Jordanian economy.

6.5.3 There is an urgent need to modernize control methods carried out by the upper neck destinations and strategic planning for Supreme Control views.

\subsection{Al-Saabary, Al-Saady (2012) Study}

Effect of INTOSAI standards on the accounting system - proposed framework

The Research aims at recognize the importance of INTOSAI organization role in developing the financial report of the governmental unit and the state as a whole, analyze the financial report in the governmental accounting 
system in Iraq, showing the effect of INTOSAI on the governmental accounting system in Iraq as well as the important requirements of developing the current financial report in the governmental accounting system in Iraq.

The Research is based on the hypothesis of (Increasing the financial report effectiveness resulted from developing the methods of measurement and report in the Iraqi accounting system and getting use of the Developed counties experiences in this field.) It was to prove this hypothesis if it comes of this research is divided into three sections to ensure the theoretical topics first under the title (the role of INTOSAI in the development of financial reporting of government) and the second section (the general budget and the impact of legislation, financial accounting system of government in Iraq), was the practical side to include the third topic entitled (INTOSAI standards impact on the accounting system of government in Iraq) and includes a calendar of financial reporting in the accounting system of government compared with INTOSAI standards, and requirements for the development of financial reporting in the accounting system of government of Iraq, came out research a set of conclusions, including: the use of cash basis modified impact on the objectives of financial statements and reports if making goals represented in the achievement of financial control, formal and traditional legal to verify the authenticity of public spending and the limits of funds appropriated without excess, and spent for its intended purpose, and collect the resources accruing to the State, and ensure compliance with laws, regulations and financial instructions. Therefore, the impact of INTOSAI standards in part on the accounting system of government. Research came out and also a set of recommendations and proposals including the issuance of the proposed framework in the search for the wealth of information useful to users in the evaluation of performance and financial position and result of operations and compliance.

\subsection{Janta et al. (2005) Study}

\section{Internal Auditing Practices and Internal Control System}

This study aimed to determine the level of commitment included in the financial market. Malaysia's Internal Auditing issued by the Institute of Internal Auditors (IIA), as well as whether to adhered to these standards affects the internal control systems in these companies. The study depends on a method of descriptive statistical analysis to describe and analyze the study variables and the testing hypotheses.

Therefore, the study concluded with a set of results, including:

6.7.1- Professional and objective internal audit departments in companies listed in the Malaysian stock market for securities companies significantly affected the efficiency of the internal control systems.

6.7.2-The scope of internal audit and professional performance of internal audit departments have an effect on the attributes of Communication and Media's internal controls and the features of the internal control system environment system.

6.7.3-The internal audit management process performs the audit work plan. Also, the internal audit report on the work of internal audit can significantly affect the risk assessment attributes of the control system.

\subsection{Kevin (2003) Study}

\section{The Effects of Internal Audit Structure on Perceived Financial Statement Fraud Prevention}

This study aimed to investigate the impact of internal audit structure on the prevailing impression among users of financial statements. The study focused on the independence of the auditor and its role in improving the work plan of the audit carried out in the United States. However, the role of the internal audit function to prevent financial fraud in the United States was estimated. The designed questionnaire fit into the theme of the study. Thus, its objectives have been distributed to all employees in the units of internal audit. The study adopted a method of descriptive statistical analysis to describe and analyze the variables of the study and the testing of the hypotheses. However, the study found the following results:

6.8.1 The impression among these officials is that the internal auditors under the guidance of their reports to senior management at the center cannot enable them to reduce fraud financial statements.

6.8.2 The Guide reviewers reported to the Board, which were at the center of a greater autonomy result as they can reduce fraud for financial statements.

6.8.3 The study did not show differences in the prevailing impression when you reduce the possibility of fraud financial statements dating back to the audit function. This function is obtained from within the company or from an external source, especially when the reports are forwarded to the Audit Committee of the Company.

\subsection{O'Regan\& David (2001) Study}

Genesis of a Profession toward Professional Status for Internal Auditing 
The study aimed to clarify the concept of professionalism in the internal auditing profession and to clarify the role of the Institute of Internal Auditors in promoting occupational and professional internal audit. The study depends on descriptive and analytical approach by studying the standards of the IIA issued according to international standards in the field of government censorship. Questionnaire have been designed and distributed to all employees in the units of the Internal Audit. However, the study relied on a method of descriptive statistical analysis to describe and analyze the variables of the study and the testing of hypotheses. One of the most important results of this study can be seen from the following conclusions:

6.9.1 The presence of the constituents of such ingredients is summarized as knowledge of the social and institutional legitimacy formed. It is formed based on a convenient and an appropriate centered ethics framework.

6.9.2 The Institute of Internal Auditors (IIA) has gone a long way to reach the professional recognition of internal audits across its inception to learn to maintain autonomy from the other knowledge. Dedication to the institutional framework includes formal institution and Institute professional certification issued by the literature, periodicals, and magazine. Also, research activities are enabled by the addition of written standards that has circulated and ethics and behaviors of the profession. However, the researcher acknowledged that more steps should be taken into account. This is regarded as the full recognition of independent craft for someone known as internal auditors.

6.9.3 The importance of internal audit section tries to emphasize the independent profession. They do not address the concept, objectives, scope, and responsibilities of the profession; its role in improving the administrative and financial performance; and its role in supporting the control systems and risk management facility.

\subsection{Smith Jones (2000) Study \\ Strengthening Internal Controls}

This study aimed to illustrate various ways to strengthen internal controls in the organizations and their importance, especially in the field of preventing and detecting errors, fraud, and mismanagement. The study depends on descriptive and analytical approach. A questionnaire was also prepared and distributed in coordination with the organizations in the United Kingdom and Australia. One of the most important findings of the study includes:

6.10.1 Internal control weaknesses would result in serious consequences. Thus, the most important is the lost through neglect and lack of attention.

6.10.2 Wastefulness resulting from deficiencies in the procedures and regulations, decisions, and misuse through the exaggeration of the proceedings and mismanagement.

6.10.3 The study concluded that the possibility of fraud does exist, and that good internal control program-on paper-does not guarantee the commitment of individuals to control procedures.

6.10.4 The effectiveness of the internal control program is a management responsibility. Thus, this was done so that there were no participation of governance at all levels. Therefore, the internal control system would not be effective.

\section{Theoretical Framework}

The objective of the financial statements is to enhance the confidence of the intended users in the financial statements. This is done by expressing the opinion of the auditor as to whether the financial statements have been prepared in all its aspects of relative significance in accordance with the applicable financial reporting framework or whether the financial statements present fairly all aspects of their relative significance or provide a true and fair view in accordance with that framework - In the case of financial statements prepared in accordance with the fair presentation framework in the financial reporting.

Laws or regulations binding on government institutions and units in the public sector may formulate this view in other ways. Auditing conducted in accordance with standards based on INTOSAI's basic financial principles and the ethical requirements involved enables the auditor to express such opinion. Standard No. 200, "Fundamental Principles of Financial Control", is the basis for the detailed financial control standards set forth in Standards (1000) to (1810) in Level 4 of the General Framework of SAIs.

As the basis for setting the criteria

As a basis for the adoption of homogeneous national standards

As the basis for the adoption of financial control guidelines as formal standards without an acceptable 
framework for financial reporting, the management will not have a proper basis for financial reporting and the auditor will not have appropriate standards for monitoring. The appropriate criteria should be formal. For example, when preparing financial statements, the standards may be IPSAS or standards (IFRS) or other international or national financial reporting frameworks for use in the public sector.

\subsection{International Standards of Supreme Audit Institutions (ISSAI)}

The International Standards for Supreme Audit Institutions (ISSAI) of the International Organization of Supreme Audit Institutions (INTOSAI) define the basic requirements and principles of the SAIs' performance of their control functions over general facilities efficiently and in accordance with professional principles, Governance guidelines for public authorities Guidelines for good governance of public funds. The International Organization of Supreme Audit Institutions (INTOSAI) was established in 1953 as an independent, independent and non-political organization to promote the exchange of views and experiences among its members, SAIs from all countries of the world in the field of government control. The principles of INTOSAI, whose value has always been demonstrated, have always been the equality of all members and their voluntary participation in the work of INTOSAI.INTOSAI applies these principles regardless of the legal framework and organizational structure of each member. It is able to develop governmental control on an ongoing and global basis in accordance with internationally accepted auditing standards, as it derives from the concepts of the governmental control developed by its members, standards and guidelines and in-depth training in the field.

In this context, it is worth mentioning the achievements of the INTOSAI committees and their working groups, which have contributed significantly to the success of INTOSAI, the success of INTOSAI's activities in INTOSAI annual training organized by the Secretariat in collaboration with UN / And the success of the United Nations Symposium by establishing internationally acceptable standards and guidelines for the functioning of SAIs, INTOSAI ultimately contributes significantly to the democratic development of nations, strengthening parliaments, strengthening government accountability, and the best possible use of public funds by the executive branch for the benefit of citizens.

\subsection{International Standard of Supreme Audit Institutions No. 200: Basic Principles of Financial Control}

The International Standard of Supreme Audit Institutions No. 200 - Basic Principles of Financial Control provides an overview of the nature, elements and principles of the audit of the financial statements. The principles presented are consistent with the ISA and the Financial Control Guidelines at Level 4 of the SAI Framework. The International Standard on Supreme Audit Institutions (SAIS) No. 200 references (links) with international standards for higher standards and provides control from 1000 to 1810 (International Standards on Auditing with Practice Notes, which contain the requirements for such review. The ISA Standard No. 200 has been developed to provide the basis for the development or adoption of auditing standards for financial control.

It is based on the same assumptions as the Financial Control Guidelines, meaning that, at the principle level, it requires the same considerations of appropriate standards and requirements of professional conduct, and requiring auditors to be part of the same quality control procedures. This international standard for SAI provides detailed information on:

- Purpose and authority of the basic principles of financial auditing,

- Purpose and authority of the basic principles of financial auditing,

- Audit framework of financial statements in the public sector,

- Elements of review of financial statements,

- Principles of review of financial statements.

7.3 The Basic Conditions for the Control of Financial Statements in Accordance with the International Standards of the Supreme Audit Institutions

7.3.1 The framework used in financial reporting is acceptable to the auditor.

7.3.2 The Authority's management acknowledges its responsibility and understanding of the following: Preparation of the financial statements in accordance with the applicable framework for financial reporting, including internal control, which the management considers necessary for the preparation of financial statements free of false data of relative importance, whether due to fraud or error; Information relevant to the preparation of the financial statements.

7.3.3 The full range of financial statements of an entity prepared in accordance with the financial reporting framework in the public sector consists of the following: Statement of financial position. Statement of changes in 
net assets / equity, statement of cash flows, comparison between budget amounts and actual amounts, disclosures that constitute a summary of significant policies and other explanatory information. The full range of financial statements may include in some other reporting environments such as performance reports and appropriation reports.

7.3.4 If the financial statements are prepared in accordance with a framework for other accounting principles as the amended accrual basis or cash basis provided for in the law or regulation, they may not include the entire set of financial statements that are acceptable from the point of view of this framework and by the auditor, but may be permitted if the following conditions are met:

If the management agrees to provide the additional disclosures required in the financial statements in order not to be misleading if the auditor's report on the financial statements includes a paragraph to draw the users' attention to such additional disclosures.

Acceptable financial reporting frameworks normally exhibit certain attributes that ensure that the information provided in the financial statements is of value to the intended users:

7.3.1.1 Relevance - the information provided in the financial statements is relevant to the nature of the audited entity and the purpose of the financial statements;

7.3.1.2 Completeness - no transactions, events, account balances or disclosures that could affect conclusions based on the financial statements are omitted;

7.3.1.3 Reliability - the information provided in the financial statements:

(i) where applicable, reflects the economic substance of events and transactions and not merely their legal form; and (ii) results, when used in similar circumstances, in reasonably consistent evaluation, measurement, presentation and disclosure;

7.3.1.4 Neutrality and objectivity - the information in the financial statements is free from bias;

7.3.1.5 Understandability - the information in the financial statements is clear and comprehensive and not open to significantly diverse interpretations.

\subsection{Standard (200) is based on the following objectives through:}

(A) The financial reporting framework used for preparation of the financial statements is deemed to be acceptable by the auditor.

(B)The management of the entity acknowledges and understands its responsibility:

\subsubsection{Ethics and Independence}

The auditor should comply with the relevant ethical requirements, including those pertaining to independence, when carrying out audits of financial statements.

Auditors conducting audits in accordance with the ISSAIs are subject to ISSAI 30 - Code of Ethics as applied in the national context. Auditors at SAIs that have adopted the level 4 ISSAIs as their authoritative standards, or that apply the ISAs, are required either to comply with the Code of Ethics for Professional Accountants issued by the International Ethics Standards.

Board for Accountants (IESBA) (the IESBA Code), which establishes fundamental ethical principles for professional accountants, or to adopt national requirements that are at least as demanding; the INTOSAI Code of Ethics applied in the national context may be relevant here.

SAIs must therefore adopt the ethical requirements of ISSAI 30 or the IESBA Code in their environment in order to be able to state in their reports that the audit was conducted in accordance with the ISSAIs or the ISAs.

\subsubsection{Quality Control}

The auditor should implement quality control procedures at the engagement level that provide reasonable assurance that the audit complies with professional standards and the applicable legal and regulatory requirements, and that the auditor's report is appropriate in the circumstances.

As stated in ISSAI 100, SAIs should adopt quality control procedures in accordance with ISSAI Quality Control for SAIs, which provides the context for the IAASB's International Standards on Quality Control (ISQC 1) in a public-sector environment. ISQC 1 establishes standards and provides guidance for an organization's system of quality control. Although the general purpose and key principles of ISSAI 40 are consistent with ISQC 1, the requirements of ISSAI 40 have been adapted to ensure they are relevant to SAIs. The Head of the SAI or the equivalent collective body has overall responsibility for introducing and maintaining quality control procedures 
in the SAI, although day-to-day operational responsibility may be delegated to others. For example, any lead auditor with responsibility for an audit engagement would ultimately report to the Head of the SAI.

Public-sector auditors engaged on audits of financial statements in accordance with standards based on or consistent with the principles of ISSAI 200 are subject to quality control requirements at the engagement level. When developing standards based on ISSAI 200 or adopting standards consistent with ISSAI 200, SAIs should consider formulating requirements related to:

- The need for the lead auditor to take responsibility for overall quality in each audit engagement;

- The need for the lead auditor to ensure that members of the audit team comply with the relevant ethical requirements;

- The need for the lead auditor to form a conclusion regarding compliance with the independence requirements that apply to the audit engagement and to take appropriate action to eliminate threats to independence;

- The need for the lead auditor to be satisfied that the audit team and any external experts collectively have the appropriate competence and capabilities;

-The need for the lead auditor to take responsibility for the performance of the audit, specifically, leading, supervising and carrying out the audit; and ensuring that reviews are conducted in accordance with the SAI's review policies and procedures.

\subsubsection{Engagement Team Management and Skills}

The auditor should be satisfied that the entire audit team, and any external experts, collectively has the competence and capabilities to:

a) Carry out the audit in accordance with the relevant standards and the applicable legal and regulatory requirements; and

b) Enable the auditor to issue a report that is appropriate in the circumstances.

When addressing the competence and capabilities expected of the team as a whole, the auditor may consider the teams:

Understanding, through appropriate training, and practical experience of audit engagements of a similar nature and complexity;

Understanding of professional standards and the applicable legal and regulatory requirements;

Technical expertise, including the relevant IT skills and knowledge of specialized areas of accounting or auditing;

Knowledge of relevant industries in which the audited organization operates;

Ability to apply professional judgement;

Understanding of the SAI's quality control policies and procedures;

Ability to discharge the terms of the audit mandate in the relevant environment, including an understanding of the applicable reporting arrangements, and to report to the legislature or other governing body or in the public interest;

Skills in the field of performance auditing or compliance auditing, if relevant.

\subsection{Financial Control Elements}

\subsubsection{The Auditor}

Shall be the executive arm of the government and / or the group of public sector bodies responsible for the management of public funds and the exercise of authority under the control of the Authority? These bodies are expected to manage the resources and exercise authority in accordance with the legislative and financial statements. And the rules issued by the legislature.

\subsubsection{The Responsible Party}

The legislature represents the citizens and they are the end users of the financial statements in the public sector and the "target user" in the first place is the parliament, which represents the citizens in the decision-making and the identification of special priorities. The decisions and foundations may constitute the public finance and the purpose and content of expenditure and income within a general democratic process for sector bodies, which are legislated by the legislature as the basis for the broader perspective of financial control in the public sector, the 
legislature and regulatory bodies are often the primary users of their financial statements.

\subsubsection{Intended Users}

The responsible party and intended users shall be from the same public entities or from different bodies. In the first case, the supervisory body of a government agency may require confirmation of the information provided by the governing body. The relationship between the responsible party and the intended users should be considered in context. The public body itself has the specific action and may differ from the limits of liability in its traditional definition.

\subsection{Financial Control Principles}

\begin{tabular}{ll}
\hline 7.6.1General Principles of Financial Control & 7.6.2Principles of Control Function \\
\hline Ethics and Independence & Agreement on the terms of the mission \\
Quality Control & Planning \\
Team Management and skills & Understand the audit entity \\
Control Risks & Risk Assessment \\
Appreciation and professional suspicion & Responses to assessed risks \\
Relative Importance & Considerations relating to fraud in the control of financial \\
& statements \\
Communications & Continuity \\
Documentation & Considerations relating to the laws and regulations in the \\
& control of financial statements. \\
Control Evidence & --------- \\
Subsequent Events & -------- \\
Evaluate erroneous data & ------ \\
Provide an opinion on the financial statements & \\
and report thereon & ---------- \\
\hline
\end{tabular}

\subsection{Financial Controls}

Financial control defined in different ways. The most important definition in my opinion, especially with regard to our subject, is that: Financial control serves the cause of increasing the practical security of society. Security is important not because it represents: one of the most important factors in the overall situation of the individual, and as such it is an important factor in describing a particular society, also because it plays a crucial role in the dynamics of social welfare growth. It is a basic economic argument that uncertainty leads to high costs, deprives development of substantial resources and, most importantly, distorts the structure of resource use, which increases efficiency.

In some public sector control environments, financial control is referred to as a control over budget execution, which often involves examining operations relative to the budget to ensure compliance and regularity issues. Such control may be conducted on the basis of risk or with a view to including all transactions. In such control environments, there is often no acceptable framework for financial reporting. The results of financial operations are presented as a comparison between expenditure amounts and budget amounts. In environments where such controls are conducted and no financial statements are presented in accordance with an acceptable framework for financial reporting, the auditor may conclude that the audit requirements established by the IFRSs are not met. Auditors may consider setting standards using the basic principles of financial control as guidance to suit specific needs. Noting the delegation of control to financial control, but not linking it to the financial statements prepared in accordance with the Financial Reporting Framework, it is suggested that IFRSs consider best available practices and apply the spirit of these standards through criteria for specific environments. To control individual financial statements for items, elements, accounts or special in the financial statements, the standard (1805) may be appropriate.

\subsection{Control of Statements Prepared under a Framework for a Specific Objective}

The principles of Standard 200 apply to the control of financial statements prepared in accordance with both general and specific frameworks. In addition to preparing general purpose financial statements, the General Assembly may prepare financial statements for other parties, such as government bodies, legislative bodies or other supervisory entities; financial statements are required to meet their specific information needs. In some entities, such financial statements are the only financial statements prepared by the General Authority and financial statements prepared for a particular purpose that are not appropriate to the general public. Therefore, 
auditors should carefully consider whether the financial reporting framework designed to meet the needs of a wide range of users (General framework), specific user needs or requirements of a standard setting body such as:

- Basis of receipts and payments for accounting of cash flow information that the Commission may have to prepare for the regulator.

- Financial reporting requirements established by an organization or legislative body or by other parties performing a supervisory function to meet the requirements of that body.

- Conditions for financial reporting in a contract;

- The principles of Standard 200 also apply to the control of public sector entities that prepare financial information, including individual financial statements, elements, accounts or special items in the financial statements of other parties (such as government agencies, legislative bodies or other parties with a supervisory function). Such information may be included in the oversight mandate of the body control.

- Auditors may also be charged with monitoring individual data, items, accounts or special items - such as government funded projects, but not the control of the full range of financial statements of the entity concerned.

\subsection{The Importance of Financial Control in the Government Sector}

The importance of financial control is to represent and ensure the proper implementation of fiscal policies. Thus, it is used to achieve the goals relating to the credibility and fairness of the financial statements and the accuracy of financial reports submitted to it. This is done in order to protect the assets of manipulation and misuse by helping to correct tracks and distractions during the execution of the plans efficiently (Arabosai, 2000, 17; Obeidat et al., 2013).

The importance and need of financial control increases by increasing the size of the administrative units and the multiplicity of its activities and programs. This importance includes the following (Rashid et al., 2012.327):

Firstly: Politically, it is used to ensure respect for the Parliament volition in the financial implementation of laws and their quest to enforce the nation volition in the use of their funds and employment.

Secondly: Financially, it is used to prevent extravagance, waste, and misuse of public funds and by commitment appropriations by monitoring specialist's expenses contract and revenue collection.

7.9.1 In accounting terms, it is used in ensuring compliance with standards, principles, integrity of the data, and accuracy of accounting.

Fourthly: Economically, it monitors the performance of authorities' activity based on the implementation of the general budget, in terms of cost and time.

7.9.2 Legally, it reflects its importance in penalties on perpetrators of errors and deviations.

7.9.3 Socially, it limits the spread of the culture of corruption and violating of the public money.

As previously noted that multi-purpose areas give financial control, there is a great capacity to adapt to environmental changes (large size of organization, unemployed time, waste of public money, consistency with organizational complexity, and reduction in errors and other environmental changes that can occur inside the unit).

7.10 Functions, Responsibilities, and the Action Mechanism of Financial Control Unit in Administrative Government Units (Hashemite Kingdom of Jordan- CSB0, 2013)

Inspection, verification, and evaluation of all activities are related to the safety and validity of financial transactions, behaviors or procedures, or human and material elements of production.

- Check and make sure that the resources have been collected and documented records are used on the dials planned.

- Verify compliance with plans, performance standards, and objectives.

- Verify that the assets, property, and production elements have been mixed, purchased, created, employed, or used in accordance with specifications, standards, plans, and has been approved.

- Be sure to provide all possible means of safety production and maintenance, protection, and preservation.

- Make sure that the use of factors of production and work procedures were in accordance with applicable legislation.

- Verification, validation and fundamentalist of records, documents and files. 
-Check and make sure that financial guarantee for tenders are in conformity with applicable regulations and instructions, and update timestamps.

- Evaluation of performance in all business areas.

- Participation in the work of the committees commissioned by the associated unit.

- Access to data and information on the scope of the tasks entrusted to the unit.

- Recommendation to repeal or modify all hampers or prevents effective functioning and effective control.

- Evaluation of administrative decisions to ensure compatibility with the existing legislation.

- Supervise the training and qualification of all employees in the unit and the dissemination of information and knowledge necessary for them and for the nature of the work to ensure continuity and quality.

- Any other tasks or duties related to the institution were determined by the General Director.

\subsection{Internal Control}

Internal control is defined as a set of methods and procedures used to develop efficient regulation and promote acceptance of sound policies and procedures in the Commission. This is used for checking the validity of information management, protection of assets, and for minimizing mistakes (ARABOSAI, 2012). Also, the Audit Committee methods of auditing procedures which emanated from the American Institute of Certified Public Accountants (AICPA), defined internal control as "organizational plan and all methods and procedures developed by the company management, which aim to preserve the company's assets and ensure the accuracy and correctness of accounting information, increase the reliability and operational efficiency, and to verify the employee commitment to administrative policies set by the administration." (ARABOSAI, 1996).

\subsubsection{Internal Control in the Public Sector}

The control of which is carried out by a set of procedures and steps to correct the work course and evaluate the completed work, and identify deviations by means and procedures aimed at protecting their assets and properties, and to verify the accuracy and accuracy of their accounting and statistical data in order to raise productive efficiency in the public sector and achieve its objectives. Internal control in the public sector helps to achieve the Unit's objectives through a systematic and disciplined approach to evaluate and improve the effectiveness of risk management and control procedures.

\subsubsection{Types of Internal Control in the Public Sector (Alkaaabr, 2013)}

\subsubsection{Financial Audit}

It is intended to analyses the economic activity of the institution and the assessment of accounting and information systems, financial reports, and reliability.

\subsubsection{Compliance Audit:}

It is a review of controls (financial and operational) to judge the quality and appropriateness of systems that have been developed to ensure compliance with regulations, legislation, and the policies set by the administration and procedures.

\subsubsection{Operational Audit:}

It is a comprehensive review of the various functions within an organization (such as sales, purchasing, production, accounting, maintenance etc.). This is aimed at ensuring the efficiency, effectiveness, and suitability of these jobs in achieving the objectives of the institution.

\section{Analysis of Questionnaire Answers and Hypotheses Testing}

Table (1): Demographic Characteristic (Description of functional variables of the study sample members)

Table (1) shows the functional variables of the study sample in terms of job title, qualification, specialization, experience years. The results show that the proportion of senior and leadership within administrative government units of sample study (28\%) is a reasonable proportion. This is because the study included (17) Ministry that include more than government Department, The table indicates that most employees in the study sample holders of bachelor's degree (75\%), Master's degree and $(0.6 \%)$ PHD shows that employees in administrative government units are qualified to conduct business efficiently and effectively.

The table above shows that most employees who hold bachelor's degree accounting specialty, has a rate of $87.5 \%$, followed by financial (6.2\%), and followed by the number of administration employees (3) with a rate of $3.8 \%$ This indicates that the specialization is consistent with the basis of recruitment and acceptances. For practical 
experience, the table above shows that most of the respondents are highly experienced in the field of internal control in the government sector. Here, the percentage of employee with experience of over 10 years was $45 \%$. However, this is an indication that the internal control staff in the administrative government units has enough expertise to carry out control functions and the ability to to understand and apply the ISSAI (200) basic principles of financial control.

\subsection{Analysis of the First Major Hypothesis}

The statistical averages, standard deviations and percentage percentages of each paragraph of the study variables were used and for the purpose of analyzing the data of the first main hypothesis, which states that "the international standards of the Supreme Audit Institutions (INTOSAI) cannot be adopted in the public sector"

This field consists of 20 items:

Table 2. Descriptive statistics for responding view's on the possibility of adopting the international standards of the Supreme Audit Institutions and INTOSAI in the public sector

\begin{tabular}{|c|c|c|c|c|c|}
\hline No. & $\begin{array}{l}\text { The adoption of international standards for the Supreme Audit Institutions in the } \\
\text { public sector }\end{array}$ & $\begin{array}{l}\text { Arithmetic } \\
\text { Mean }\end{array}$ & $\begin{array}{l}\text { Standard } \\
\text { Deviation }\end{array}$ & $\begin{array}{l}\text { Order of } \\
\text { importance } \\
\text { paragraph }\end{array}$ & Level \\
\hline 1. & Government administrative units independence & 4.826 & 0.760 & 1 & High \\
\hline 2. & $\begin{array}{l}\text { Verify the validity and } \\
\text { integrity of the application of the applicable financial } \\
\text { legislation }\end{array}$ & 4.799 & 0.966 & 3 & High \\
\hline 3. & $\begin{array}{l}\text { Full knowledge of the basic information required for the nature of the audited } \\
\text { entity }\end{array}$ & 3.744 & 1.021 & 14 & High \\
\hline 4. & The control process is based on the pre-planned control plan. & 3.972 & 0.899 & 10 & High \\
\hline 5. & $\begin{array}{l}\text { Ensure the scope of control in terms of type of control, procedures, time, nature, } \\
\text { and in line with any legislation and laws committed by the audited entity. }\end{array}$ & 4.101 & 0.789 & 9 & High \\
\hline 6. & $\begin{array}{l}\text { Ensure that the prepared planning has been done carefully, objectively and under } \\
\text { appropriate supervision. }\end{array}$ & 4.802 & 0.932 & 2 & High \\
\hline 7. & $\begin{array}{l}\text { Audit documents based on adequate and appropriate audit evidence to verify their } \\
\text { validity and their values. }\end{array}$ & 4.706 & 0.895 & 4 & High \\
\hline 8. & $\begin{array}{l}\text { Ensure that the evidence of the control consist of, material, documentary and } \\
\text { analytical. }\end{array}$ & 4.548 & 0.710 & 6 & High \\
\hline 9. & $\begin{array}{l}\text { Internal control units develop a detailed program of financial control of } \\
\text { administrative government units. }\end{array}$ & 3.714 & 0.852 & 15 & High \\
\hline 10. & $\begin{array}{l}\text { Evaluate the reliability of the internal control systems of the audited entity } \\
\text { according to the appropriate control objectives. }\end{array}$ & 4.632 & 0.784 & 5 & High \\
\hline 11. & $\begin{array}{l}\text { Establish control procedures by collecting sufficient and appropriate regulatory } \\
\text { evidence according to standards or a specific framework consistent with } \\
\text { regulations and legislation. }\end{array}$ & 3.850 & 0.641 & 13 & High \\
\hline 12. & $\begin{array}{l}\text { Refers in his report to the standards that have been followed and the criteria that } \\
\text { have been applied during the control process. }\end{array}$ & 4.210 & 1.070 & 8 & High \\
\hline 13. & The report is complete, objective, convincing, clear and timely & 4.232 & 1.021 & 7 & High \\
\hline 14. & $\begin{array}{l}\text { The auditor's report was widely disseminated to the public opinion, which supports } \\
\text { the credibility and integrity of the audit work in accordance with INTOSAI } \\
\text { standards. }\end{array}$ & 3.907 & 1.010 & 12 & High \\
\hline 15. & $\begin{array}{l}\text { Follow up previous and current reports as a tool to strengthen future monitoring } \\
\text { and development }\end{array}$ & 3.956 & 0.962 & 11 & High \\
\hline \multicolumn{2}{|c|}{ The arithmetic mean and general standard deviation } & 4.266 & 0.887 & -- & High \\
\hline
\end{tabular}

Table (2) shows the responses of the study sample in the administrative government this is about the statements concerning the possibility of adopting the international standards of the Supreme Audit Institutions of INTOSAI in the public sector. Here, the arithmetic ranging for this variable is between $(3.714-4.826)$ with an overall average of (4.266) on a pentalikert scale, Thus, this indicates the high-level of the adoption of international standards for the Supreme Audit Institutions (INTOSAI) in government administrative units. Paragraphs $(15,1)$ 
occupied a high level because the requirements of the standards were very consistent with the laws, regulations and legislations. This indicates the effective role of the administrative units in the departments and administrative units under their control, especially in these aspects.

\subsection{Analysis of the Second Major Hypothesis}

"The ISSAI 200 Standard "Financial Principles of Auditing" cannot be applied in the public sector"

The statistical averages, standard deviations and percentages of each paragraph of the study variables were used and for the purpose of analyzing the data of the first main hypothesis, which states that "ISSAI 200 can not apply the basic principles of financial control in the public sector".

Table 3. Descriptive statistics for responding view's on the applicability of the ISSAI 200 "Basic Principles of Financial Control" in the public sector.

\begin{tabular}{|c|c|c|c|c|c|}
\hline No. & $\begin{array}{l}\text { Application of ISSAI } 200 \text { "Basic principles of financial control" in } \\
\text { government administrative units }\end{array}$ & $\begin{array}{l}\text { Arithmetic } \\
\text { Mean }\end{array}$ & $\begin{array}{l}\text { Standard } \\
\text { Deviation }\end{array}$ & $\begin{array}{l}\text { Order of } \\
\text { importance } \\
\text { paragraph }\end{array}$ & Level \\
\hline 16. & $\begin{array}{l}\text { Compliance with the requirements of professional ethics regarding } \\
\text { independence in the control of financial statements. }\end{array}$ & 4.012 & 0.892 & 1 & High \\
\hline 17. & $\begin{array}{l}\text { The Controller states that the audit was carried out in accordance with the } \\
\text { international standards of the SAIs or the International Financial Control } \\
\text { Standards. }\end{array}$ & 3.965 & 1.056 & 2 & middle \\
\hline 18. & $\begin{array}{l}\text { Provide reasonable assurance that the audit is in compliance with professional } \\
\text { standards and applicable legal and regulatory requirements. }\end{array}$ & 3.710 & 1.026 & 5 & High \\
\hline 19. & The auditor is responsible for the overall quality of each work of the audit & 3.912 & 0.986 & 3 & High \\
\hline 20. & $\begin{array}{l}\text { The auditor shall ensure that the members of the audit team comply with the } \\
\text { ethical requirements }\end{array}$ & 3.435 & 1.622 & 9 & middle \\
\hline 21. & $\begin{array}{l}\text { Ensure that audits are conducted in the policies and procedures of the Supreme } \\
\text { Audit Institutions. }\end{array}$ & 3.388 & 1.025 & 10 & middle \\
\hline 22. & $\begin{array}{l}\text { The auditor has the know-how that includes relevant IT skills and knowledge } \\
\text { in the areas of control and accounting. }\end{array}$ & 3.589 & 0.996 & 7 & High \\
\hline 23. & Knowledge of relevant industries in which the audited entity operates. & 3.307 & 1.114 & 11 & middle \\
\hline 24. & $\begin{array}{l}\text { Has skills in the area of performance control and compliance control as the } \\
\text { case. } \\
\text { Ability to implement the terms of the control function in the relevant } \\
\text { environment according to the legislature or other regulatory body or the public }\end{array}$ & 3.801 & 1.071 & 4 & High \\
\hline 26. & $\begin{array}{l}\text { interest. } \\
\text { The auditor shall perform a comprehensive review of the various functions in } \\
\text { the administrative unit to ensure that }\end{array}$ & 3.455 & 0.978 & 8 & middle \\
\hline & $\begin{array}{l}\text { The efficiency, effectiveness and suitability of these functions in achieving the } \\
\text { objectives of the establishment }\end{array}$ & 3.707 & 1.087 & 6 & High \\
\hline 27. & $\begin{array}{l}\text { Examination, verification and evaluation of all aspects of activity related to the } \\
\text { integrity and validity of transactions Financial actions or work procedures or } \\
\text { components of human and material production. }\end{array}$ & 3.244 & 1.655 & 12 & middle \\
\hline \multicolumn{2}{|r|}{ The arithmetic mean and general standard deviation } & 3.649 & 1.114 & -- & High \\
\hline
\end{tabular}

Table (3) shows answers of the study sample in the administrative government units for phrases related to the applicability of ISSAI 200, "Basic principles of financial control. The arithmetic ranging for this variable is between (3.244 - 4.012) with an overall average of (3.649) on a pentalikert scale, Thus, this indicates the high-level of implementation of the ISSAI 200 principles. Paragraph (16) ranked first under the title "Compliance with the requirements of professional ethics regarding independence in the control of financial statements" with average arithmetic mean of 4.012 because it met the laws and regulations. The standard was followed by paragraph (27) Verification and evaluation of all aspects of activity relating to the safety and validity of transactions and financial transactions or work procedures or components of human and material production ", 
with average arithmetic mean of 3.244 and a standard deviation (1.655) This is due to the nature of some administrative units, which cannot be examined and evaluated for all the activity in it for its specificity, and the regulations, laws or legislation to a large extent did not confirm the examination of all activities and contrary to the standard No. (200) of the basic principles of financial control.

\subsection{Analysis of the Third Major Hypothesis}

"There is no statistically significant impact on internal control when applying ISSAI 200" Fundamental Principles of Financial Control "in the public sector. This field includes (12) items.

Table 4. The descriptive statistics of respondents' views on the impact on internal control when applying ISSAI 200 "Basic Principles of Financial Control" in the public sector.

\begin{tabular}{|c|c|c|c|c|c|}
\hline No. & $\begin{array}{l}\text { A statistically significant impact on internal control when applying ISSAI } 200 \\
\text { "Basic Principles of Financial Control" in the public sector }\end{array}$ & $\begin{array}{l}\text { Arithmetic } \\
\text { Mean }\end{array}$ & $\begin{array}{l}\text { Standard } \\
\text { Deviation }\end{array}$ & $\begin{array}{l}\text { Order of } \\
\text { importance } \\
\text { paragraph }\end{array}$ & Level \\
\hline \multirow{2}{*}{$\begin{array}{l}28 . \\
29 .\end{array}$} & Assess the assetability of abuse. & 3.587 & 0.963 & 5 & High \\
\hline & $\begin{array}{l}\text { Efficiency or disability when complying with laws and regulations and adhering } \\
\text { to the objectives of ethical behavior and economic objectives. }\end{array}$ & 3.021 & 0.403 & 9 & middle \\
\hline 30. & Identify and understand relevant regulatory controls. & 3.962 & 0.672 & 4 & High \\
\hline 31. & Determine what is exactly about the effectiveness of controls. & 3.120 & 1.306 & 8 & middle \\
\hline 32. & Assess the adequacy of controls design. & 3.210 & 0.975 & 7 & middle \\
\hline 33. & $\begin{array}{l}\text { Communicate the results of the internal audit evaluation and discuss the } \\
\text { necessary corrective actions. }\end{array}$ & 4.156 & 0.298 & 3 & High \\
\hline 34. & $\begin{array}{l}\text { Carry out different roles and responsibilities in the internal control both within the } \\
\text { administrative unit and outside it in accordance with the legislations and policies } \\
\text { set. }\end{array}$ & 3.502 & 0.976 & 6 & High \\
\hline 35. & $\begin{array}{l}\text { Internal control takes into account both the regulatory environment, risk } \\
\text { assessment, control activities, information, reporting and control when initiating } \\
\text { its procedures. }\end{array}$ & 3.005 & 1.059 & 10 & middle \\
\hline 36. & $\begin{array}{l}\text { Internal control uses information technology or controls designed to protect data } \\
\text { and information as to unauthorized modifications or to protect against loss or } \\
\text { disclosure. }\end{array}$ & 4.326 & 0.361 & 2 & High \\
\hline 37. & $\begin{array}{l}\text { Permanent and continuous cooperation with the Financial Control Authority, } \\
\text { which is appointed, operated or organized to perform external control functions in } \\
\text { accordance with applicable laws. }\end{array}$ & 4.486 & 0.369 & 1 & High \\
\hline The & rithmetic mean and general standard deviation & 3.590 & 0.789 & --- & High \\
\hline
\end{tabular}

Table 4 shows the effect of internal controls on the application of ISSAI 200, "Basic principles of financial control" in the public sector with the arithmetic range for this variable is between (4.486 - 3.005) with an overall average of 3.590 on pentalikert scale. Thus this is referring to the high Application Standard for ISSAI 200 "Fundamental Principles of Financial Control. Paragraph (37) ranked first under the title "Permanent and continuous cooperation with the Financial Control Authority, which is appointed, operated or organized to perform external control functions in accordance with applicable laws." with average arithmetic mean of (4.486) As it is integrated with what governs the work of the Controller and the work of internal auditing that have the same work nature, as required by Standard No. 200 "Fundamental Principles of Financial Control, Paragraph (35) tenth place entitled" Internal control taking into account both the regulatory environment and risk assessment and control activities with an arithmetic mean of (3.005) and standard deviation (1.059). This is due to the fact that the regulations and legislations are incomplete, sophisticated, or can be developed. This leads to procedural weakness, which cannot be examined and evaluated for all aspects of activity. Pussy what came standard number (200) basic principles of financial control.

\subsection{Analysis of the Fourth Major Hypothesis}

"There are no impediments to the application of ISSAI 200" Basic Principles of Financial Control "in the public sector" 
Table 5. Descriptive Statistics of Respondents' Views on Constraints Limits the Application of ISSAI 200 "Basic Principles of Financial Control in the Public Sector.

\begin{tabular}{|c|c|c|c|c|c|}
\hline No. & $\begin{array}{l}\text { Constraints that limit the application of ISSAI } 200 \text { "Basic principles of financial } \\
\text { control" in the public sector }\end{array}$ & $\begin{array}{l}\text { Arithmetic } \\
\text { Mean }\end{array}$ & $\begin{array}{l}\text { Standard } \\
\text { Deviation }\end{array}$ & $\begin{array}{l}\text { Order of } \\
\text { importance } \\
\text { paragraph }\end{array}$ & Level \\
\hline 38. & High bureaucracy in the completion of daily financial transactions. & 4.021 & 1.003 & 1 & High \\
\hline 39. & Less experience in the areas of specialization required. & 2.968 & 1.407 & 10 & Weak \\
\hline 40. & Insufficient working hours to carry out work. & 3.760 & 0.940 & 5 & High \\
\hline 41. & Lack of reward system and incentives. & 3.821 & 1.056 & 3 & High \\
\hline 42. & Aging or non-updating of available computer and technological equipment. & 3.901 & 1.036 & 2 & High \\
\hline 43. & Appointment is not for need but for different grounds. & 3.026 & 1.026 & 9 & middle \\
\hline 44. & $\begin{array}{l}\text { The statute of limitations of some laws, regulations and instructions, and not to } \\
\text { modify them and comply with standards. }\end{array}$ & 3.605 & 1.012 & 4 & High \\
\hline 45. & Weakness in training courses and lectures. & 3.448 & 1.149 & 8 & middle \\
\hline 46. & $\begin{array}{l}\text { Non-response by the administration to the reports issued by financial observers, } \\
\text { especially the amendments and improvements. }\end{array}$ & 3.707 & 1.113 & 6 & High \\
\hline 47. & $\begin{array}{l}\text { Weak decision-making time is appropriate and appropriate for administrative and } \\
\text { financial leaders. }\end{array}$ & 3.522 & 1.622 & 7 & middle \\
\hline The & rithmetic mean and general standard deviation & 3.417 & 1.118 & --- & middle \\
\hline
\end{tabular}

Table (3) shows answers of the study sample in the administrative government units for phrases related to the constraints on the application of the ISSAI 200 standard "Financial Principles of Financial Control" in the public sector. Here, the arithmetic range for this variable is between 4.021, 2.968 with an overall average of (3.617) on pentalikert scale, indicating the average level of constraints Application of ISSAI 200 Standard "Financial Principles of Auditing" in the public sector. Paragraph (28) ranked first under the title "High bureaucracy in the completion of daily financial transactions." With arithmetic mean of (4.021) which is higher than the general arithmetic mean (3.417) and Standard deviation (1.118). While paragraph (29) "Less experience in the areas of specialization required" occupied the tenth and last order with an arithmetic mean of (2.968) which is lower the general arithmetic mean (3.417) and standard deviation (1.407). Overall, the level of impediments to the application of the ISSAI 200 standard "financial principles of control" in the public sector is evident. From sample study view, it was average because the above constraints are not an obstacle to the application of ISSAI 200, "Basic Principles of Financial Control", but paragraphs $(33,29)$ represent a barrier from the viewpoint of respondents limiting the possibility of applying Standard ISSAI 200 "Fundamental Principles of Financial Control," and agreed.

\section{Hypotheses Test}

\subsection{First Major Hypothesis}

HO1: "International Standards for Supreme Audit Institutions (INTOSAI) cannot be adopted in the public sector" In testing this hypothesis, the researcher used T-test for one sample this is used to verify the adoption of international standards for the Supreme Audit Institutions (INTOSAI) in government administrative units, as shown in Table (6).

Table 6. The results of the $\mathrm{T}$ test to verify the adoption of the international standards of the Supreme Audit Institutions of INTOSAI in the public sector.

\begin{tabular}{llllllll}
\hline $\begin{array}{l}\text { First major } \\
\text { hypothesis }\end{array}$ & NO. & $\begin{array}{l}\text { Arithmetic } \\
\text { Mean }\end{array}$ & $\begin{array}{l}\text { Standard } \\
\text { Deviation }\end{array}$ & DF & $\begin{array}{l}\text { Calculated } \\
\text { T value }\end{array}$ & $\begin{array}{l}\text { Tabulated } \\
\text { T value }\end{array}$ & Sig* \\
\hline $\begin{array}{l}\text { International Standards for Supreme } \\
\begin{array}{l}\text { Audit Institutions (INTOSAI) cannot } \\
\text { be adopted in the public sector }\end{array}\end{array}$ & & & & & & \\
\hline
\end{tabular}

Demonstrated by the results shown in the table (6), The International Standards for Supreme Audit Institutions (INTOSAI) can be adopted and applied at the level of significance $(\alpha \leq 0.05)$. The calculated T- value function is 
(14.226) and the indication level is given as $\alpha \leq 0.05$ when compared with Tabulated $T$-Value (1.053). The table also shows the same level indication (0.000). As a result, The International Standards for Supreme Audit Institutions (INTOSAI) can be adopted and applied in public sector. The premise of nihilism (zero) is accepted and the alternative hypothesis is rejected if the calculated value is less than the tabular value and the moral (Sig) is greater than 0.05 . Also, the null hypothesis $(\mathrm{HO})$ is rejected if the calculated value is greater than the tabular value. On the other hand, if the value of the moral (Sig) is less than 0.05 ; we reject the null hypothesis and accept the alternative hypothesis. Thus, this hypothesis states that:

"The possibility of adopting the international standards of the Supreme Audit Institutions of INTOSAI in the public sector".

\subsection{Major Hypothesis}

HO2:"ISSAI 200 standard cannot be applied to the" basic principles of financial control "in the public sector

In testing this hypothesis, the researcher used T-test for one sample this is used to verify the possibility of applying ISSAI 200 "Fundamental Principles of Financial Control" in the public sector, as shown in Table 7.

Table 7. The results of the T test - The possibility of applying ISSAI 200 "Fundamental Principles of Financial Control" in the public sector.

\begin{tabular}{llllllll}
\hline $\begin{array}{l}\text { Second major } \\
\text { hypothesis }\end{array}$ & NO. $\begin{array}{l}\text { Arithmetic } \\
\text { Mean }\end{array}$ & $\begin{array}{l}\text { Standard } \\
\text { Deviation }\end{array}$ & DF & $\begin{array}{l}\text { Calculated } \\
\text { T value }\end{array}$ & $\begin{array}{l}\text { Tabulated } \\
\text { T value }\end{array}$ & Sig* $^{*}$ \\
\hline $\begin{array}{l}\text { The posipility of applying ISSAI 200 } \\
\text { "Fundamental Principles of Financial }\end{array}$ & & & & & & & \\
\begin{tabular}{l} 
Control" in the public sector \\
\hline
\end{tabular} & 80 & 3.649 & 1.114 & 85 & 9.856 & 1.752 & 0.000 \\
\hline
\end{tabular}

Demonstrated by the results shown in the table (7) The possibility of applying ISSAI 200 "Fundamental Principles of Financial Control" in the public sector has a significance level $(\alpha \leq 0.05)$. The calculated T- value function is 9.856 and the indication level is given as $\alpha \leq 0.05$ when compared with Tabulated T -Value (1.752). The table also shows the same level indication (0.000). As a result, there is a possibility of applying ISSAI 200 "Fundamental Principles of Financial Control" in the public sector

\subsection{Major Hypothesis}

HO3: "There is no statistically significant effect on internal control when applying the ISSAI 200 standard"

In testing this hypothesis, the researcher used T-test for one sample this is used to verify the influencing internal control through ISSAI 200 implementation of the "Basic Principles of Financial Control" in the public sector, as shown in Table 8.

Table 8. The results of the T test- There is no statistically significant effect on internal control when applying the ISSAI 200 standard

\begin{tabular}{lllllll}
\hline $\begin{array}{l}\text { Third major } \\
\text { Hypothesis }\end{array}$ & NO. $\begin{array}{l}\text { Arithmetic } \\
\text { Mean }\end{array}$ & $\begin{array}{l}\text { Standard } \\
\text { Deviation }\end{array}$ & DF $\begin{array}{l}\text { Calculated } \\
\text { T value }\end{array}$ & $\begin{array}{l}\text { Tabulated } \\
\text { T value }\end{array}$ & Sig* \\
\hline
\end{tabular}

There is no statistically significant effect on internal control when applying the ISSAI 200 standard

Demonstrated by the results shown in the table (8): There is no statistically significant effect on internal control when applying the ISSAI 200 standard" has a significance level $(\alpha \leq 0.05)$. The calculated T- value function is 12.109 and the indication level is given as $\alpha \leq 0.05$ when compared with Tabulated T -Value (1.209). The table also shows the same level indication (0.000). As a result, there is no statistically significant effect on internal control when applying the ISSAI 200 standard

\subsection{Major Hypothesis}

HO4: There are no impediments to the application of ISSAI 200, "Basic principles of financial control" in the public sector" 
Table 9. The results of the T test- -There are no impediments to the application of ISSAI 200, "Basic principles of financial control" in the public sector

\begin{tabular}{llllllll}
\hline $\begin{array}{l}\text { Fourth major } \\
\text { Hypothesis }\end{array}$ & NO. $\begin{array}{l}\text { Arithmetic } \\
\text { Mean }\end{array}$ & $\begin{array}{l}\text { Standard } \\
\text { Deviation }\end{array}$ & DF $\begin{array}{l}\text { Calculated } \\
\text { T value }\end{array}$ & $\begin{array}{l}\text { Tabulated } \\
\text { T value }\end{array}$ & Sig* $^{*}$ \\
\hline $\begin{array}{l}\text { There are no impediments to the } \\
\text { application of ISSAI 200, "Basic } \\
\text { principles of financial control" in the } \\
\text { public sector }\end{array}$ & & & & & & & \\
\hline
\end{tabular}

Demonstrated by the results shown in the table (9): there are impediments to the application of ISSAI 200, "Basic principles of financial control" in the public sector has a significance level $(\alpha \leq 0.05)$. The calculated Tvalue function is 8.963 and the indication level is given as $\alpha \leq 0.05$ when compared with Tabulated $T$-Value (1.208). The table also shows the same level indication (0.000). As a result, there are no impediments to the application of ISSAI 200, "Basic principles of financial control" in the public sector.

\section{Results and Recommendations}

\subsection{Results}

Based on data analysis and hypothesis testing, the study found a set of results:

10.1.1The international standards of the Supreme Audit Institutions (INTOSAI) in the public sector in general can be adopted with average arithmetic mean of (4.232) and a standard deviation (1.021). The result is based on the financial regulations and legislations for financial control.

10.1.2ISSAI 200, "Basic Principles of Financial Control" in the public sector in general, can be applied to a high degree with an arithmetic mean of (3.649) and a standard deviation (1.114). The result is that the financial controls in accordance with Standard No. 200 of the International Standards for Machines However, there were some differences in some of the responses to some paragraphs in relation to some governmental administrative units, which led to a decrease in the arithmetic mean and some of the standard deviation on the light So.

10.1.3Effect on internal control in the application of ISSAI 200, "Basic principles of financial control" in the public sector "at the level of significance $\alpha \leq 0.05$ generally, it came at a high level with an arithmetic mean of (3.590) and a standard deviation (0.789) The financial controls in accordance with ISSAI 200 of the international standards of the Supreme Audit Institutions (INTOSAI) are highly compatible with what has been legislated for the administrative units of the government regarding the procedures of the internal control work. Therefore, we note from the above analysis that there is a significant effect to some extent except the efficiency clause states Deficit when compliance with laws and regulations and adherence to the aims of moral behavior and economic goals, a return to the privacy of internal control in the administrative units in the public sector. $\leq \alpha$ - Effect on internal control in the application of ISSAI 200, "Basic principles of financial control" in the public sector "at the level of significance $\alpha \leq 0.05$.

10.1.4There are obstacles that limit the application of the ISSAI 200 standard "Basic Principles of Financial Control" in the public sector generally came with an average arithmetic 3.417 and standard deviation of (1.118). The researcher attributed this result to the presence of some of the most important obstacles as follow:

A- High bureaucracy in the completion of daily financial transactions.

B - The statute of limitations of some laws, regulations, and instructions and didn't modify them and conform to standards.

C - Adjustment not for need but for different establishment.

D- Lack of response by the Administration to the reports issued by the financial controller, especially it's amendments and improvements.

10.1.5 The international standards of the Supreme Audit Institutions of INTOSAI can be adopted and applied at the level of significance $(\alpha \leq 0.05)$.

10.1.6 The possibility of applying the ISSAI 200 "Basic Principles of Financial Control" in the public sector "at the level of significance $(\alpha \leq 0.05)$.

10.1.7 There is an impact on internal control in the application of ISSAI 200, "Basic principles of financial control" at the significance level $(\alpha \leq 0.05)$. 
10.1.8 There are impediments to the application of the ISSAI 200 standard "financial principles of control" in the public sector at the level of significance $(\alpha \leq 0.05)$.

\subsection{Recommendations}

In light of the above, the researcher provides a set of recommendations:

10.2.1 Paying attention to the employment cadres and working to keep up with the development and modernization of the international standards of the supreme bodies of financial control and accounting INTOSAI.

10.2.2 Emphasize the need to reformulate some of the legislation and instructions for some of the financial aspects.

10.2.3 Work on the development of strategies and plans of financial control. Also, it should take into account the availability of experience, skills and capabilities of the managers, and the employees of administrative government units.

10.2.4 The need for harmonization between the legislation and regulations with international professional standards especially the supreme control standards of what lends importance and effectiveness to financial control.

10.2.5 Permanent and continuous cooperation between legislators and the applicable bodies of the standards to reach a consensus and appropriate in some minor or fundamental differences between the law and the standard.

\section{References}

Al- hawatmeh, O. (2016). The extent of internal control units in the government sector with the regulatory standards of the international organization of supreme audit control bodies (INTOSAI) in Jordan. Journal of Management Research, 8(4).

Al-hawatmeh, O., \& Al-Hawatmeh, Z. (2016). Evaluation of internal control units for the effectiveness of financial control in administrative government units: A field study in Jordan. European Scientific Journal, 12(13).

Alkaaabr, M. (2013). Appropriateness of audit procedures to fight corruption. Unpublished MA Thesis, University of the Middle East, Jordan.

Al-Saabary, I., \& Al-Saady, H. (2012). Effect of INTOSAI standards on the accounting system-proposed framework. College of Administrative Technology / Kufa, Iraq.

American Psychological Association. (1972). Ethical standards of psychologists. Washington, DC: American Psychological Association.

Arab Group of Supreme Accounting Control (1996.219).

Arab Organization of Supreme Audit Institutions (Arabosai, 2000).

Arab Organization of Supreme Audit Institutions (Arabosai, 2006).

Arab Organization of Supreme Audit Institutions (Arabosai, 2012).

Hararah, S. (2016). The impact of efficiency and effectiveness of financial control on rationalize expenditure case study (Aqaba Special Economic Zone Authority). Middle East University, Jordan.

Institute of Internal Auditors IIA (2004). Code of ethics and standards for the professional practice of Internal Auditing.

Institute of Internal Auditors IIA (2010).

Institute of Internal Auditors IIA (2011). Internal Auditing Role in Risk Management.

International standards for devices Supreme Audit Institutions, issued by the International-Organization of Supreme Audit Institutions (INTOSAI) 2006. Retrieved from http://www.issai.org

Kevin (2003). The effects of internal audit structure on perceived financial statement fraud prevention. Accounting Horizons, 17(4), 1-17.

Obeidat, B., El-Rimawi, S., Maqableh, M., \& Al-Jarrah, I. (2013). Evaluating the profitability of the Islamic banks in Jordan. European Journal of Economics, Finance and Administrative Sciences, 56, 27-36.

O'Regan \& David (2001). Genesis of a profession: Towards professional status for internal auditing. Managerial Auditing Journal, 16(4), 215-226. 
Sawalha et al. (2013). Renewed senior government control methods according to the requirements of the privatization: A case study in Jordan. Journal of Baghdad College of Economic Sciences, 36.

Shetwer, A. (2014). The contribution of internal control to improving the financial performance of the economic institution examines the case of the Asian banking institution in Skra (E.G.T.B). Mohammed Khiedr University-Biskra-Algeria.

Smith, D., \& Jones, D. (2000). Strengthen in internal controls armed forces comptroller. Internal Control, 45(3), 339.

The Hashemite Kingdom of Jordan- CSC0 (2013). The ministry of finance, applied FAQ for financial affairs No. 1/1995, Administrative Development and Training Directorate, Amman, Jordan, updated, S94-96.

\section{Copyrights}

Copyright for this article is retained by the author(s), with first publication rights granted to the journal.

This is an open-access article distributed under the terms and conditions of the Creative Commons Attribution license (http://creativecommons.org/licenses/by/4.0/). 